\title{
Learning by the book: manuals and handbooks in the history of science
}

\author{
Angela N.H. Creager ${ }^{1 *}$, Mathias Grote ${ }^{2}$ and Elaine Leong ${ }^{3}$ \\ ${ }^{1}$ Department of History, Princeton University, 129 Dickinson Hall, Princeton, NJ 08544-1174, USA, \\ ${ }^{2}$ Institut für Geschichtswissenschaften, Humboldt-Universität zu Berlin, Unter den Linden 6, 10099 \\ Berlin, Germany and ${ }^{3}$ Department of History, University College London, Gower Street, London, \\ WC1E 6BT, United Kingdom \\ *Corresponding author: Angela Creager, email: creager@princeton.edu
}

\begin{abstract}
This essay offers an overview of how manuals and handbooks have contributed to the standardization, codification, transmission and revision of knowledge. These instructional and reference texts are distinct from related educational genres such as textbooks and editions due to their focus on practical knowledge. They are also notable for their appearance in diverse times and places, such as ancient Greece, early and medieval China and early modern Europe, as well as modern contexts worldwide. We are especially interested in the role of these often mundane texts in maintaining and resituating old knowledge, whose importance is discounted when scholars focus on innovation. Modern notions of authorship fit poorly with handbooks and manuals, which are generally derivative of other literature, though they often result in more commercially successful texts than their sources. This introduction draws on book history as well as history of science to offer a framework for the volume.
\end{abstract}

Often overlooked, manuals, handbooks and protocols are key tools in the making and managing of knowledge, not least in science. Across learned societies, artisanal workshops and biomedical laboratories, instructional texts and compendia codify the knowledge of a working community, with an eye to communicating what a new practitioner needs to know. Instructional and reference texts have also played a key role in bringing local knowledge and know-how to far-flung readers and practitioners around the globe. This volume of Themes, Learning by the Book, brings together the history of science and the history of the book to consider, put in simplest terms, how practices relate to texts and learning relates to doing. To pick up a familiar philosophical distinction, this orientation allows a historian to study the knowing how of the sciences as opposed to the knowing that documented in articles, monographs or textbooks. ${ }^{1}$ What is more, this volume's articles use manuals and handbooks as a focal point for a geographically and temporally extended perspective on knowledge transmission. We contend that following how-to texts, along with their makers and users, brings into view a neglected set of historical connections and participants.

1 Gilbert Ryle, The Concept of Mind, London: Hutchinson, 1949.

(C) The Author(s), 2020. Published by Cambridge University Press on behalf of British Society for the History of Science. This is an Open Access article, distributed under the terms of the Creative Commons Attribution-NonCommercial-NoDerivatives licence (http://creativecommons.org/licenses/by-nc-nd/4.0/), which permits non-commercial re-use, distribution, and reproduction in any medium, provided the original work is unaltered and is properly cited. The written permission of Cambridge University Press must be obtained for commercial re-use or in order to create a derivative work. 
How do practitioners - of any form of specialized knowledge - learn technical skills and know-how? Or how do they retrieve knowledge deemed solid and secure? Recent studies have illuminated how knowledge and skills were often passed on orally or by repeated practice within workshops and more. ${ }^{2}$ Clearly, much scientific training occurs formally, such as in schools and laboratories. These have attracted due attention from historians, notably with a focus on how experts convey working knowledge, usually in person, to their students or apprentices. ${ }^{3}$ But learning does not stop with formal education, and often enough it starts elsewhere. Within communities of researchers and practitioners, like laboratory groups and households, manuals have long enabled as well as accompanied self-directed education and training. Learning from books rather than from masters removes the traditional hierarchy of the classroom, but can also involve other power dynamics, especially when instructional materials are elements of governance or set workplace or domestic standards.

of course, there are many genres of instructional text, including textbooks and editions; our volume focuses specifically on those used 'at hand' for the practical doing of science. These range from texts such as artisanal manuals offering instruction for craft skills to large encyclopedic 'handbooks' oriented towards pedagogy or designed to ease information retrieval. Considering examples from diverse historical contexts, we will scrutinize how scientific knowledge and know-how become reconfigured through book production, how these texts facilitate technical training and monitoring, and how manuals and handbooks figure in the marketplace for leisure reading and self-improvement as well as for scientific work. ${ }^{4}$ In doing so, this volume extends the reach of book history into studies of science, technology and medicine. ${ }^{5}$

\section{Handy knowledge? Concepts and metaphors}

Manuals and handbooks have a long and cross-cultural history, stretching back to ancient times. Practical knowledge did not need to be written down, as it was usually passed from master to apprentice, thus textual instructions reflect certain cultural conditions of literacy, mobility and circulation of textual media. Within the European context, etymologically, manuals and handbooks should mean the same thing: they are books 'on hand', or held in the hand, for instruction, help, reference, review, even as a place to store additional handwritten notes. The Greek term encheiridion, designating also a dagger, a handle or even a napkin, was first used to refer to a text in late antiquity, most famously for an extract of Stoic philosophy attributed to Epictetus, which became known simply as The Encheiridion. ${ }^{6}$ The other meanings of the term remained in play; as Matteo Martelli

2 Tim Ingold, The Perception of the Environment: Essays on Livelihood, Dwelling and Skill, London: Routledge, 1989; Pamela Smith, 'In the workshop of history: making, writing, and meaning', West 86th: A Journal of Decorative Arts, Design History, and Material Culture (2012) 19, pp. 4-31.

3 Kathryn Mary Olesko, Physics as a Calling: Discipline and Practice in the Königsberg Seminar for Physics, Ithaca, NY: Cornell University Press, 1991; Gerald L. Geison and Frederic L. Holmes (eds.), Research Schools: Historical Reappraisals, Osiris (1993) 8; Andrew Warwick, Masters of Theory: Cambridge and the Rise of Mathematical Physics, Chicago: The University of Chicago Press, 2003; David Kaiser (ed.), Pedagogy and the Practice of Science, Cambridge, MA: MIT Press, 2005; Suman Seth, Crafting the Quantum: Arnold Sommerfeld and the Practice of Theory, 1890-1926, Cambridge, MA: MIT Press, 2010; Feike Dietz and Sven Dupré, 'Youthful minds and hands: learning practical knowledge in early modern Europe', Science in Context (2019), pp. 113-18.

4 Natasha Glaisyer and Sara Pennell, Didactic Literature in England 1500-1800: Expertise Constructed, Aldershot and Burlington, VT: Ashgate Publishing, 2003, p. 3.

5 Marina Frasca-Spada and Nick Jardine (eds.), Books and the Sciences, Cambridge: Cambridge University Press, 2000; James A. Secord, Victorian Sensation: The Extraordinary Publication, Reception, and Secret Authorship of Vestiges of the Natural History of Creation, Chicago: The University of Chicago Press, 2003.

6 Ulrike Brandt, Kommentar zu Epiktets Encheiridion, Heidelberg: Universitätsverlag Winter, 2015, Introduction. 
mentions in his contribution to this volume, the Byzantine grammarian George Choeroboscus referred to Hephaestion's condensed treatise on Greek metres as an encheiridion not only on account of its portability but also the fact that its teachings were as sharp as a sword. ${ }^{7}$ Marta Hanson's paper on related books in imperial China reminds us of the semantic plurality of not only the hand, but also the fingers (pointing) or the palm (holding) as ready metaphors for practical knowledge.

Over time the term encheiridion (latinized as enchiridion) referred to other texts on subjects as diverse as astrology, music or alchemy. In the medieval period, the Latin manuale and vademecum were also used for such texts. ${ }^{8}$ Literally 'go with me', books under this latter title presented guidelines and repeatedly hint at a close, if not intimate, relationship between textual material and a reader. By the age of print, these terms were adapted to refer to small handheld books used to codify knowledge in areas from science to politics, as well as for the teaching of the catechism. ${ }^{9}$ Within the European context, the early modern period saw a particularly rich and diverse culture of instructional texts on subjects as diverse as medicine, instrumentation, navigation and fortification. ${ }^{10}$ This proliferation of manuals was part of a broader burgeoning of technical literatures, including texts in manuscript as well as print, from cheap ephemera to expensive tomes, with a wide range of functions. ${ }^{11}$

The differentiation between manual and handbook has never been clear-cut, and, to make things worse, French only knows the manuel, while German relies on the Handbuch. Yet there is evidence that the spectrum of literature designated especially by the Germanic term changed significantly in the modern period. By the early nineteenth century, scientific and technological handbooks had developed a tendency to become 'unhandy' - that is, quite heavy - books, and entire book series began to appear under this title. This transformation was certainly enabled by changes in the history of publication, such as the introduction of the steam-powered printing press and the mechanized production of cheap paper. Alongside these technological changes, the formation of scientific disciplines entailed other forms of writing, storing and circulating knowledge in pedagogy and in technical practice, further encouraging the expansion of instructional or reference literature. ${ }^{12}$ Many such handbooks were not restricted (if they ever had been) to merely conveying instructional information. Rather, they offered the précis of a discipline or field, or ordered inventories of their objects, such as of chemical substances or biological species. ${ }^{13}$ Similar examples exist in many other fields of specialization - one

7 Martelli, this volume.

8 André Crépin, 'The transmission of learning in the early Middle Ages: Byrhtferth's Enchiridion', Caliban (2011) 29, pp. 21-30; Joseph A. Kechichian and R. Hrair Dekmejian, The Just Prince: A Manual of Leadership, London: Saqi, 2003; C.H. Talbot, 'A medieval physician's vade mecum', Journal of the History of Medicine and Allied Sciences (1961) 16, pp. 213-33.

9 Ian Green, The Christians's ABC: Catechisms and Catechizing in England c. 1530-1740, Oxford: Clarendon, 1996.

10 For a recent overview see Matteo Valleriani (ed.), The Structures of Practical Knowledge, Heidelberg: Springer, 2017; and Adrian Johns, 'Science and the book', in John Barnard and D.F. McKenzie (eds.), The Cambridge History of the Book in Britain, vol. 5: 1557-1695, Cambridge: Cambridge University Press, 2002, pp. 274-303.

11 Pamela O. Long, 'Manuals', in Ann Blair, Paul Duguid, Anja Goeing and Anthony Grafton (eds.), Information: A Historical Companion, Princeton, NJ: Princeton University Press, forthcoming 2021. See also Elizabeth Tebeaux, The Emergence of a Tradition: Technical Writing in the English Renaissance, 1475-1640, Amityville, NY: Baywood Publishing Company, 1997; Tebeaux, The Flowering of a Tradition: Technical Writing in England, 1641-1700, London: Routledge, 2015.

12 James A. Secord, 'Science, technology and mathematics', in David McKitterick (ed.), The Cambridge History of the Book in Britain, vol. 6: 1830-1914, Cambridge: Cambridge University Press, 2009, pp. 443-74.

13 See contribution by Grote in this volume, who documents the formation of a specific 'unhandy' encyclopedic handbook in the nineteenth century. Lexicographic evidence also supports this development. The Oxford English Dictionary introduces the 'handbook' as 'originally: a book small enough to be easily portable and intended 
need only point to the Diagnostic and Statistical Manual of Mental Disorders (DSM), now in its fifth edition of 991 pages. In brief, while short instructional manuals could obviously still be found, and in fact proliferated under the novel conditions of cheap industrial print, the nineteenth century saw the emergence of a novel type of reference handbook, not so much portable as 'at-hand' versions of authoritative knowledge (sometimes called, in a similarly paradoxical way, compendia, or shortcuts). ${ }^{14}$

These comprehensive handbooks emerged in response to other changes in the production, circulation and differentiation of scientific literatures, not least the emergence of the modern scientific journal as a periodical form of print, and the research article, as described by Alex Csiszar. ${ }^{15}$ Michael Gordin has analysed the appearance of a paragon of such an unhandy Handbuch, Beilsteins Handbuch der organischen Chemie, a systematically ordered inventory of carbon-based chemical substances and their properties, which became a pivotal reference book of the field. ${ }^{16}$ As the contribution by Mathias Grote suggests, such encyclopedic handbooks, self-evident in daily scientific practice until the late twentieth century, inspired Ludwik Fleck to distinguish the genres of popular science and Zeitschriftwissenschaft (journal science) from the Handbuchwissenschaft (vademecum or handbook science). In his classic Entstehung und Entwicklung einer wissenschaftlichen Tatsache (1935), he argued that handbooks, particularly in the life sciences and medicine, functioned as a way of categorizing and ordering the expanding amount of knowledge arising from the publication of articles in periodicals. ${ }^{17}$ Handbooks of this sort became continually revised desktop and library references that could no longer be held in one hand (or carried under an arm), but that may still have transported a form of knowledge 'at hand', i.e. factual or objective knowledge for rapid access. ${ }^{18}$

Needless to say, the work which brought Fleck to wider attention, particularly for Anglo-American scholars, is Thomas Kuhn's Structure of Scientific Revolutions. ${ }^{19} \mathrm{Kuhn}$ also noted the role of instructional literature, in this case textbooks, which for him were key to teaching paradigms. In recent years, partly in response to Kuhn, textbooks have received a great deal of attention by scholars working in the history of education. ${ }^{20}$

to be kept close to hand'; however, it then suggests a conceptual development: 'Later also more generally: any book (usually but not necessarily concise) giving information such as facts on a particular subject, guidance in some art or occupation, instructions for operating a machine, or information for tourists'. See also Grimms Wörterbuch for the German language: Deutsches Wörterbuch von Jacob und Wilhelm Grimm, 16 vols. in 32, Leipzig: Hirzel, 1854-1961, Bd. $10 \mathrm{H}, \mathrm{I}, \mathrm{J}$ (1877) online version as of 15 November 2018, at www.woerterbuchnetz.de/ DWB?lemma=handbuch.

14 Hansun Hsiung, 'Knowledge made cheap: global learning and the logistics of printing', Publications of the Modern Language Association of America: PMLA (2019) 134, pp. 137-43.

15 Alex Csiszar, The Scientific Journal: Authorship and the Politics of Knowledge in the Nineteenth Century, Chicago: The University of Chicago Press, 2018.

16 Michael D. Gordin, 'Beilstein unbound: the pedagogical unraveling of a man and his Handbuch', in Kaiser, op. cit. (3), pp. 11-39.

17 Ludwik Fleck, Entstehung und Entwicklung einer wissenschaftlichen Tatsache: Einführung in die Lehre vom Denkkollektiv, Frankfurt am Main: Suhrkamp, 1980 (first published 1935), pp. 146 ff. 'Vademecum' clearly misses a central point of the Handbuch; see contribution by Grote, this volume.

18 A particular mix of manual and handbook in this sense, as an encyclopedic compendium of methods, is provided by Emil Abderhalden's Handbuch der biologischen Arbeitsmethoden, 107 vols., Berlin: Urban \& Schwarzenberg, 1919-39.

19 Thomas S. Kuhn, The Structure of Scientific Revolutions, 2nd edn, Chicago: The University of Chicago Press, 1970 , p. 46.

20 Kaiser, op. cit. (3); Bernadette Bensaude-Vincent, Antonio García Belmar and José-Ramon Bertomeu Sanchez, L'émergence d'une science des manuels: Les livres de chimie en France, Paris: Archives Contemporaines Editions, 2003; Emidio Campi, Simone De Angelis, Anja-Silvia Goeing and Anthony T. Grafton (eds.), Scholarly Knowledge: Textbooks in Early Modern Europe, Geneva: Librarie Droz, 2008; J. Simon, 'Textbooks', in Bernard Lightman (ed.), A Companion to the History of Science, Chichester: John Wiley \& Sons, 2016, pp. 400-13. 
While textbooks are the most easily identifiable genre of publications for teaching, Anthony Grafton observes that historians may overlook other kinds of instructional media, particularly editions of classic texts. ${ }^{21} \mathrm{~A}$ few studies, such as Lorraine Daston and Peter Galison's landmark Objectivity, have focused on scientific media with both a representational and an instructional function, such as atlases. ${ }^{22}$ However, their emphasis is on what secured the authority of these reference works more than on their users. Coming from another angle, scholars working on premodern science have introduced us to the world of books of secrets, craft and artists' manuals, and instructional guides for architects and engineers. ${ }^{23}$ Some of them have even put the instructional function of historic protocols to the test by trying to follow their methods or replicate key results. ${ }^{24}$ This has been valuable in revealing what critical elements are excluded from - or encrypted in such texts. Re-enactments of this kind have been particularly important for recovering alchemical and artisanal knowledge and practice. ${ }^{25}$

Handy or unhandy, on the table or on the shelf: from this brief survey, it is obvious that handbooks and manuals provide a way to connect the history of science with that of the book sensu latu, thereby providing more than a genre history. Texts of these kinds, often relatively low-status as works of instruction or synthesis rather than reports of new knowledge, were aimed at particular problems of scientific communication, such as how to convey bodily practices or update conventional wisdom. In addition to the question of how to make things explicit (or not) is the challenge of how to apportion knowledge in order to transmit and transport it, or how to set out a step-by-step procedure that a reader or, maybe more fittingly, 'user' can execute. In recent years, scholars have analysed annotations, correspondence and oral history to recover what readers can learn from a text, how users continually test and adjust instructions, and which unstated experiences or skills ('tacit' or otherwise) must be gained in other ways. ${ }^{26}$ As Staffan

21 Anthony T. Grafton, 'Textbooks and the disciplines', in Campi et al. op. cit. (20), pp. 11-38; Alain Bernard and Christine Proust (eds.), Scientific Sources and Teaching Contexts throughout History: Problems and Perspectives, Dordrecht: Springer, 2014, especially Anne Chartier, 'The teaching context and reading from the sixteenth to the nineteenth centuries: the role of the memorization of texts in learning' (pp. 19-40).

22 Lorraine Daston and Peter Galison, Objectivity, New York: Zone Books, 2010.

23 William Eamon, Science and the Secrets of Nature: Books of Secrets in Medieval and Early Modern Culture, Princeton, NJ: Princeton University Press, 1994; Pamela Smith, The Body of the Artisan: Art and Experience in the Scientific Revolution, Chicago: The University of Chicago Press, 2004; Pamela O. Long, Openness, Secrecy, Authorship: Technical Arts and the Culture of Knowledge from Antiquity to the Renaissance, Baltimore and London: Johns Hopkins University Press, 2001.

$24 \mathrm{H}$. Otto Sibum, 'Reworking the mechanical value of heat: instruments of precision and gestures of accuracy in early Victorian England', Studies in History and Philosophy of Science (1995) 26, pp. 73-106; Hasok Chang, 'How historical experiments can improve scientific knowledge and science education: the cases of boiling water and electrochemistry', Science \& Education (2011) 20, pp. 317-41; Pamela H. Smith, 'Historians in the laboratory: reconstruction of Renaissance art and technology in the Making and Knowing Project', Art History (2016) 39, pp. 210-33; and Thijs Hagendijk, 'Learning a craft from books: historical re-enactment of functional reading in gold- and silversmithing', Nuncius (2018) 33, pp. 198-235.

25 Lawrence Principe, "“Chemical translation" and the role of impurities in alchemy: examples from Basil Valentine's Triumph-Wagen', Ambix (1987) 34, pp. 21-30; Jennifer M. Rampling, 'Transmuting sericon: alchemy as "practical exegesis" in early modern England', Osiris (2014) 29, pp. 19-34; Smith, op. cit. (2).

26 On the reading, testing and amending of instructional texts see Sven Dupré, 'Doing it wrong: the translation of artisanal knowledge and the codification of error', in Valleriani, op. cit. (10), pp. 167-88; and Elaine Leong, Recipes and Everyday Knowledge: Medicine, Science and the Household in Early Modern England, Chicago: The University Of Chicago Press, 2018, esp. Chapters 3 and 4. On tacit knowledge see Michael Polanyi, Personal Knowledge: Towards a Post-critical Philosophy, Chicago: The University of Chicago Press, 1958; Jerome R. Ravetz, Scientific Knowledge and Its Social Problems, Oxford: Clarendon Press, 1971, esp. Chapter 3; Harry M. Collins, Changing Order: Replication and Induction in Scientific Practice, Chicago: The University of Chicago Press, 1985. Scholars studying laboratory notebooks probe similar issues: Frederic L. Holmes, Jürgen Renn and Hans-Jörg 
Müller-Wille and Giuditta Parolini show in this volume, even scientific publications not intended for instruction can become primers, if readers find them useful for learning something new. ${ }^{27}$ Moreover, there are long-standing questions related to collecting and sorting knowledge, and shaping it into the form of a book, which have been especially well studied for encyclopedic projects of the early modern period, but which await attention for later periods. ${ }^{28}$

In order to address handbooks and manuals as a genre, as texts as well as artefacts, this Themes volume on Learning by the Book brings into consideration a geographically and temporally extended array of instructional and reference literature, ranging from antiquity to the late twentieth century. The texts under consideration do not all resemble what a present-day reader may expect of a book, and even some with a conventional format, as Boris Jardine shows, include elements to be used in ways beyond reading. We introduce the case studies in three thematic (but admittedly overlapping) groups, according to the angle they take on these books: (1) the making of manuals and handbooks, (2) their uses and (3) their afterlives. We then end our introduction with some reflections on how this longue durée collective history can help us reconsider the temporality of scientific knowledge.

\section{The making of handbooks and manuals}

Matteo Martelli offers a conceptual genealogy of small instructional texts of late Greek antiquity, focusing on encheiridia in music, astrology or devotional guides, and adding to the spectrum recipe books from alchemy. Such ancient handbooks aimed to convey the fundamental concepts, maxims or methods of a learned or moral discipline. He focuses on one such encheiridion of alchemy, a recipe book from the Graeco-Egyptian alchemist Zosimus of Panopolis. While this was reputed to be part of a larger mythical book of twenty-four tomes revealed by fallen angels, deriving its authority from divine knowledge, many of Zosimus' recipes were passed down in Syriac translation as loosely organized collections containing practical instructions. Thus handbooks transmit knowledge that may not be intended for usage, as protocols and instructions may have been incorporated into compilations and texts with other purposes. What is more, Martelli illustrates a fundamental tension faced by his alchemical authors, and one may suspect by this genre more generally, between claims to systematically order knowledge and what he calls a 'polyphonic textual tradition'; that is, discrete textual units that were flexibly compiled, updated, expanded or reduced.

Rheinberger (eds.), Reworking the Bench: Research Notebooks in the History of Science, Dordrecht: Kluwer Academic Publishers, 2003. For an ethnographic example see Kathleen Jordan and Michael Lynch, 'The sociology of a genetic engineering technique: ritual and rationality in the performance of the "Plasmid Prep"', in Adele E. Clarke and Joan H. Fujimura (eds.), The Right Tools for the Job: At Work in Twentieth-Century Life Sciences, Princeton, NJ: Princeton University Press 1992, pp. 77-114.

27 Cf. the case of John Herschel's 'Preliminary discourse on the study of natural philosophy' as discussed in James A. Secord, Visions of Science: Books and Readers at the Dawn of the Victorian Age, Chicago: The University of Chicago Press, 2015.

28 Richard Yeo, Encyclopaedic Visions: Scientific Dictionaries and Enlightenment Culture, Cambridge: Cambridge University Press, 2001; Ann M. Blair, Too Much to Know: Managing Scholarly Information before the Modern Age, New Haven, CT: Yale University Press, 2010; Richard Yeo, Notebooks, English Virtuosi, and Early Modern Science, Chicago: The University of Chicago Press, 2014; Helmut Zedelmaier, Werkstätten des Wissens zwischen Renaissance und Aufklärung, Tübingen: Mohr Siebeck, 2015; Anthony Grafton and Glenn W. Most (eds.), Canonical Texts and Scholarly Practices: A Global Comparative Approach, Cambridge: Cambridge University Press, 2016; and Elisabeth Décultot and Helmut Zedelmaier (eds.), Exzerpt, Plagiat, Archiv: Untersuchungen zur neuzeitlichen Schriftkultur, Halle: Mitteldeutscher Verlag, 2017. 
Marta Hanson's longue durée history of medical instructional manuals calls attention to the diverse and multilvalent metaphors used by Chinese authors to signal usability and orientational knowledge. Analysing book titles, Hanson shows that if European authors turned to the hand as the dominant metaphor, Chinese authors took a different and winding path. In the early medieval period, authors signalled the portability and value of their knowledge by using a number of 'container metaphors' such as 'kerchief-box' editions or Jade Case Formulary (Yuhan fang 玉函方), and highlighted the addition of various verse forms to medical texts originally in prose by using terms such as 'mnemonic formula' ( jue 訣), 'rhapsody' ( fu 賦) and 'song' or 'ditty' (ge 歌). Intended to ease memorization, versification of medical texts, along with other strategies of simplification, continued into the late medieval period. With the growth of literacy and expansion of commercial medical publishing in the Ming period, new metaphors such as mirrors, heart-mind, palm and fingers emerged. Hanson's close reading of book titles reveals a wide range of metaphors, descriptors and genre distinctions which signalled strategies used to facilitate the learning of medicine by the book, manifesting new ways of formulating, managing and popularizing knowledge. By tracing the emergence and disappearance of terms, Hanson's long-view study offers a new perspective on how Chinese authors used metaphors and titles in their attempts to make a complex and ever-expanding textual medical archive more accessible to a broader readership.

In the field of natural history, handbooks may be aimed at readers beyond those we might regard as scientific practitioners. Federico Marcon takes us to eighteenth-century Tokugawa Japan to investigate how knowledge of nature was transmitted in 'canonical encyclopedias', highly elaborated collectors' items. Such lavishly illustrated artefacts, often customized with commentaries or personalized texts, served both epistemological and social functions among scholars organized in clubs. Importantly, as Marcon argues, canonical encyclopedias were not merely the end point, but also the starting point for investigations of nature. He shows how textual practices of comparison, adaption, amendment or correction, e.g. with Chinese or incoming Western knowledge and to a lesser degree from observation, fed into Tokugawa Japan's bookish universe of nature. Updating existing books, instead of producing them from scratch, necessitated integrating new and old knowledge, and thus infused authors with a responsibility to represent a dynamic canon of knowledge within a hierarchic network of different textual genres. Not least, the case of canonical encyclopedias exemplifies the unstable relation of books to knowledge of nature, an epistemological undercurrent of this Themes volume that transcends geographical and temporal boundaries.

Taking into view modern handbooks of chemistry and the life sciences, Mathias Grote takes up the thread provided by Martelli in providing further evidence for the complex conceptual genealogy of the genre since the nineteenth century. He compares the making and the development of two books that represented pivotal encyclopedic repositories of information in their fields, the American Bergey's Manual of Determinative Bacteriology (on microbes) and the German Gmelins Handbuch der anorganischen Chemie (on chemical substances). His paper analyses how specialized knowledge deemed established and relevant became usable 'at hand' in what paradoxically developed into heavy tomes. He focuses particular attention on the Sisyphean labour involved with compiling an ever-increasing and faster-ageing corpus of knowledge in an effort to maintain book projects over the longue durée and the illusion of a stable canon. This history of encyclopedic handbooks reveals unexpected authorial figures (editors, invisible assistants) and textual practices (excerpting, indexing) that are at odds with received narratives of the modern experimental sciences, and that more closely resemble those found in earlier natural history.

Anna-Maria Meister's article unearths the fascinating political and personal history of an unpublished German manual, here in the realm of architecture: Ernst Neufert's 
'Lebensgestaltungslehre'. Neufert is known for his seminal Bau-Entwurfslehre, first published in 1936, which presented standardized solutions for building 'everything' from dog kennels to offices to Zeppelins. By contrasting Neufert's published handbook projects with the still fragmented 'Lebensgestaltungslehre', distributed across his unpublished index-card diary, Meister reveals how what one may call the spirit of the modern handbook, i.e. a normalizing, technocratic way of thinking and working, has materialized beyond the covers of a book. She argues forcefully that Neufert's highly ambivalent concept of design (Gestaltung) and measurement, inspired by divisibility and control, pervaded his mirror projects of ordering life and formatting German society - under National Socialism and thereafter.

In sum, these five accounts of the making of handbooks and manuals (as well as other contributions discussed below) provide evidence for our premise that a genre of instructional literature can be identified in different centuries and continents, both before and after print. The cases also suggest a set of shared textual practices involved in the making of handbooks and manuals, such as compilation, excerpting and indexing. ${ }^{29}$ Here the production, or reproduction, of canonical knowledge is usually the goal, rather than either novelty or credit. The compilers and editors involved in making handbooks and manuals may resemble the adjunct or clerical figures that Robert Darnton has highlighted as so central to the writing of the Encyclopédie. ${ }^{30}$ In a similar vein, Nick Jardine has spoken of 'routine authorship' in science. He suggests that scholars take into account the textual activities at the core of making scientific books as physical artefacts, which are generally 'dismissed as mechanical, derivative, second-rate or inauthentic according to Cartesian or Romantic concepts of authorship. ${ }^{31}$ A key question for Jardine, and for us, is whether and how such seemingly mundane texts may have in turn also contributed to the generation of new knowledge.

This Themes volume, in turn, links our topic with historical studies of collecting, archiving and classifying as activities that create resources for future inquiry - from naturalhistorical investigations, to the gathering of textual documents, to data resulting from observation or experiments. Handbooks and manuals often derived from and codified other texts and inscriptions, e.g. preliminary scribbles such as protocols or recipes, lists and tables, commentaries, a mass of ephemeral journal articles, lab notebooks, perhaps even a diary. In addition, many such projects were linked to large publishing ventures of seemingly mundane texts, often featuring data rather than instructional or reference knowledge - atlases, catalogues, tables, etc. - whose relation to handbooks deserves further attention. ${ }^{32}$ The modern notion of a singular author may be poorly suited for these sources of scientific text. Hans-Jörg Rheinberger has suggested that these diverse kinds of scientific text, in which we would include guidebooks and reference works, might be better understood as 'technologies of literacy'.33

29 For recent overviews on the scholarly practices of compiling, commentating and annotating see Dana Jalobeanu, 'The toolbox of the early modern natural historian: notebooks, commonplace books and the emergence of laboratory records', Journal of Early Modern Studies (2015) 4, pp. 107-23; Boris Jardine, 'State of the field: paper tools', Studies in History and Philosophy of Science Part A (2017) 64, pp. 53-63; Elaine Leong, 'Read. Do. Observe. Take note!', Centaurus (2018) 60, pp. 87-103.

30 Robert Darnton, The Business of Enlightenment: A Publishing History of the Encyclopédie, 1775-1800, Cambridge, MA: Harvard University Press, 2009.

31 Nick Jardine, 'Books, texts and the making of knowledge', in Frasca-Spada and Jardine, op. cit. (5), pp. 393$408,400$.

32 Lorraine Daston (ed.), Science in the Archives: Pasts, Presents, Futures, Chicago: The University of Chicago Press, 2017; Bruno Strasser, Collecting Experiments: Making Big Data Biology, Chicago: The University of Chicago Press, 2019.

33 Hans-Jörg Rheinberger, 'Discourses of circumstance: a note on the author in science', in Mario Biagioli and Peter Galison (eds.), Scientific Authorship: Credit and Intellectual Property in Science, New York and London: Routledge, 2003, pp. 309-24. 


\section{Using manuals and handbooks}

In our second set of papers we turn to how manuals and handbooks are used. We begin with books for which the technological uses extended beyond literacy. Boris Jardine presents the striking case of actual mathematical instruments that could be made from the printed pages of a manual. A key example is John Blagrave's Mathematical Jewel, with its plates to be cut out, fastened onto pasteboard or wood, and assembled into a functioning instrument for astronomical calculation. These were instructional texts, to be sure, but readers learned mathematics by doing, not simply by reading. Moreover, the existence of manuals clearly did not render expert instrument-makers obsolete; rather, books encouraging astronomical practice enhanced the market for instruments made by master craftsmen. In addition, instrument books (as well as other texts such as almanacs and images) were used in artisanal workshops, not only by 'amateurs', and so codified and transmitted design details used in manufacture. More generally, mathematical practices in early modern England, such as the geometry of projection, involved various kinds of 'paperwork' for which how-to books were central. ${ }^{34}$ The existence of this remarkable genre of manuals destabilizes the commonly held distinctions between knowing and doing, reading and making, manual labour and cognition.

Stephanie Dick also deals with mathematical instructional literature, but three centuries later, when a new kind of tool became available, the computer. The development of digital algebraic systems, such as Project MAC's Symbolic Manipulator (MACSYMA), offered mathematicians, physicists and engineers a powerful new tool for solving computational problems. However, learning how to use MACSYMA was a non-trivial task, and equally challenging was communicating how to use it. Dick's contribution highlights the disciplinary function of instructional texts, which aim to control as much as empower their users. Several texts, including the MACSYMA Reference Manual and a shorter Primer, were aimed at guiding users into becoming so-called planners, able to formulate computational steps in terms the system could solve. This entailed getting users to think differently about their problems. Even as the expert-system practitioners struggled to make MACSYMA comprehensible to mathematically advanced users (who still turned to conferences for in-person training), they rejected the notion that the existence of tacit knowledge might be part of the inadequacy of their manuals, primers and reference books.

Angela Creager looks at a 1982 manual for cloning genes that sold nearly 100,000 copies in its first decade. Researchers used these codified instructions (a manual dubbed their 'bible' by users) alongside standardized reagents, 'libraries' of genes, and purified enzymes to join the so-called recombinant DNA revolution that swept through biology in the 1980s. Molecular Cloning: A Laboratory Manual had its genesis in an oversubscribed summer course at Cold Spring Harbor Laboratory. There was a forty-year tradition of such courses at this renowned lab on Long Island, and laboratory manuals had been published by the instructors for several of the popular courses. Molecular Cloning outsold every other book the laboratory press had ever issued, and its ubiquity in biology labs helped to standardize the methods and experimental approaches that led into the era of the Human Genome Project. But following this manual through its several editions cautions us against overemphasizing the stability of knowledge. New methods, reagents and protocols meant that between editions users constantly updated manuals, and some laboratories simply even compiled their own customized manuals both to keep up and to make sure that everyone was using the same techniques. Even so, technical obsolescence was (and is) a constant problem for biologists trying to keep at the forefront of research.

34 Ursula Klein, Experiments, Models, Paper Tools: Cultures of Organic Chemistry in the Nineteenth Century, Stanford, CA: Stanford University Press, 2003. 
In focusing on use, the papers in this section engage an issue that historians of science have long pondered: that of the relationship between reading, writing and doing. These contributions showcase instructional texts as objects in use, open to continual revision based on practice, a theme that features also in the next section. The papers also point to the various elements of manuals and handbooks that can function independently, such as the paper instrument, the algorithm or the recipe. In recent years, the recipe in particular has received consideration from historians of the early modern period, in ways that could inspire new work on the more recent past and cross-cultural exchange. ${ }^{35}$ Scholars working on art, culinary and medical recipes have used a range of methodologies, from reconstruction and re-creation to close readings of marginal annotations, to tease out the various epistemic processes which connect text to action. For example, recent reconstruction work on artists' recipes has demonstrated how the maker's knowledge of materials, technologies and the body was central to interpreting and using recipes. By working through the art recipes in BNF Ms. Fr. 640, for instance, Pamela Smith and her team at the Making and Knowing Project bring to the fore the manuscript author-practitioner's 'material imaginary' - his 'system of knowledge about nature and the behavior of natural materials'. ${ }^{36}$ BNF Ms. Fr. 640 is riddled with annotations, revisions and rewrites, reflecting on its author-practitioner's continual search for and refinement of know-how.

While many of these studies of recipes emphasize the complicated relationship between text and action, it is worth bearing in mind that not all technical manuals were designed to be used for step-by-step instruction. Craig Clunas's research on late Ming Chinese craft manuals, for instance, makes clear that some manuals, such as the Xiushilu 髹飾錄 (Records of Lacquering) were designed to educate consumers and cultivate connoisseurship, whilst others, such as the Lu Ban jing 魯班經 (Classic of Lu Ban) were geared towards imparting practical knowledge like carpentry. ${ }^{37}$ And even when manuals did provide explicit how-to instructions, they were also teaching users how to think differently - whether these were computer programmers, gene cloners or, as we encounter in the next section with Jenny Rampling's paper, aspiring alchemists.

\section{Afterlives of manuals and handbooks}

Not surprisingly, perhaps due to their authoritative and often accessible nature, many manuals and handbooks remain in use decades or hundreds of years after their initial debut. A number of stories in our collection highlight the complex afterlife of instructional texts. Karine Chemla's essay examines commentaries from the third century CE in China, which commented upon 'ancient algorithms' from The Nine Chapters on Mathematical Procedures to solve problems imperial officials faced. By the seventh century

\footnotetext{
35 For an overview see Michelle DiMeo and Sara Pennell (eds.), Reading and Writing Recipe Books, 1550-1800, Manchester: University of Manchester Press, 2013. Recent work on medical recipes includes Marta Hanson and Gianna Pomata, 'Medicinal formulas and experiential knowledge in the seventeenth-century epistemic exchange between China and Europe', Isis (2017) 108, pp. 1-25; Leong, op. cit. (26); and Alisha Rankin, Panaceia's Daughters: Noblewomen as Healers in Early Modern Germany, Chicago: The University of Chicago Press, 2013. On artisanal and craft recipes see Pamela H. Smith, 'Why write a book? From lived experience to the written word in early modern Europe', Bulletin of the German Historical Institute (2010) 47, pp. 25-50; Smith, op. cit. (2); Smith, op. cit. (24); Dupré, op. cit. (26); and Thijs Hagendijk, 'Unpacking recipes and communicating experience: the Ervarenissen of Simon Eikelenberg (1663-1738) and the art of painting', Early Science and Medicine (2019) 24, pp. 248-82.

36 Smith, op. cit. (24), 221.

37 Craigh Clunas, 'Luxury knowledge: the Xiushilu ("Records of lacquering”) of 1625', Techniques \& Culture: Revue semestrielle d'anthropologie des techniques (1998) 29, pp. 27-40.
} 
CE, early mathematical texts like The Nine Chapters, together with the third-century commentary, were compiled into the Ten Canons of Mathematics. She observes that modern historians tend to see these texts as merely administrative and educational in a modern sense, whereas she attempts to historicize how these texts were instructional. Chemla's detailed exploration of commentaries on The Nine Chapters underscores commentary writing as a way of learning and amplifying existing knowledge. Two layers of commentary, dating to different epochs, updated and customized canonical procedures of Chinese mathematics to function within new material and intellectual contexts. Though penned hundreds of years apart, these commentaries became integrated into the text, separated and signalled only by paratextual clues. Through her excavation of these layers, Chemla invites readers to appreciate how new scenarios for solving a problem can literally change the canon.

Jennifer Rampling's contribution on early modern treatises of 'alchemical philosophy' also complicates the idea of instructional literature, demonstrating that these texts imparted more than technical know-how. To further their theoretical and practical knowledge, sixteenth-century alchemists turned to texts written by pre-Reformation authorities, bringing these medieval manuscripts to a new generation of readers. To become an alchemist, one had to learn how to read alchemically, Rampling argues, and this could be done, despite the obscurity of alchemical treatises, 'by the book'. It is through reading that adepts gained the skills to decipher the texts passed down to them. To further their knowledge, alchemists exchanged annotated books with each other, thereby creating conversations between writers and readers across time and space.

As we all know, readers can also become authors. Elaine Leong's study of a mid-seventeenth-century English surgical guide by the little-known practitioner Thomas Brugis shows how traditional tools of learning such as compilation in turn produced new texts. Here, the selection and reassemblage of texts was not only a device for learning but a way to orient a knowledge field or set of practices. Brugis's lists of key surgical instruments and medicines tread the fine line between instruction and prescription. Responding to the changing needs of book users and producers, the 'handiness' of the Vade mecum fluctuated across time and space. While Brugis compresses the traditional surgical manual to recipe-like instructions, the later editor/compiler of the Vade mecum, Ellis Pratt, reinserted the theoretical discussions of the human body and surgical ailments that Brugis once purposefully omitted. Later readers, some contemporary and some working as late as the nineteenth century, further expanded Brugis's text with marginal annotations, creating their own customized sets of know-how.

Continuing this theme of excavating reading practices, Staffan Müller-Wille and Giuditta Parolini's contribution examines the various editions of Gregor Mendel's republished classic pea-cross paper (including textbooks and English translations) and follows its uses as instructional literature. In tracing how biologists read and utilized Mendel, they argue that the emergence of Mendelian genetics was less about the spread of a theory than about that of a protocol. Moreover, the annotations they have found on the widely circulated editions of Mendel's paper document, quite literally, readers learning genetics by the book, trying out calculations and playing with various kinds of annotations and diagrams for crosses, as well as correcting errors in the text. Offering a timely caution against too strong a divide between the research literature and manuals, their study shows how a neglected text can be revived and put to practical ends in new social, material and pedagogical contexts.

As the four essays in this section illustrate, reading and writing practices such as commentating, compiling and annotating were key to the production and use of instructional manuals across knowledge fields. Through these practices, generations of book producers and users 'braided' together existing (often long-standing) and new knowledge, to borrow 
Projit Mukharji's term. ${ }^{38}$ As such, these long-view histories of single texts prompt us to re-examine notions of change in the history of science. ${ }^{39}$ Whereas past studies have tended to focus on novelty and invention, our case studies push us to reconsider innovation as interpretation, extension or reclassifying of the canon.

Over time, of course, readers' uses may diverge from authors' intentions. The authors of the early modern alchemical manuals Rampling described might have been trying to train users to read like alchemists, but, at times, readers preferred to understand the text as a practical guide. In other cases, makers of instructional literature responded to users, updating or explicating sections of the manuals. In Creager's study, for example, the authors of Molecular Cloning, working in a rapidly changing field, were always mindful of the tension between offering instructions that were at once reliable and state-of-the-art. Highly anticipated new editions contained new and updated methods, expanding into multiple volumes. Not only was the content changing: in an effort to keep pace with digital formats, the press turned to multimedia technologies in the 1990s and finally to digital platforms in the early 2000s. For Leong's surgical manual, the original author aimed for a short book but readers added in other material over time. The enduring nature of instructional manuals thus often depended on their ability to change with the times.

This tension between comprehensiveness and concision seems especially important to the genre of instructional and reference literature. The literal enlargement over time of a manual or handbook can prompt the development of a subsidiary - or rival - 'essential' guide that conveys the information in a more digestible and portable way. In Creager's paper, for instance, the subscription-based Current Protocols in Molecular Biology, with their volumes' three-ring binders to accommodate each quarter's new additions, was supplemented within two years by the hard-bound Short Protocols in Molecular Biology: A Compendium of Methods from Current Protocols in Molecular Biology. Compression and expansion remained irreconcilable aims for the maker of a manual or handbook, as reflected in the partial differentiation of those two terms in English. ${ }^{40}$ Especially in the modern period, the pace of scientific publication threatens to overwhelm the contained order of knowledge in an authoritative guide - or render it altogether obsolete.

\section{Past knowledge in an age of new media}

This collection shows that knowledge can become 'old' in different ways, such as by becoming generally known, revised or antiquated. ${ }^{41}$ Moreover, the articles invite us to ask new questions about settled knowledge. How are traditional practices and protocols preserved or discarded, and how are the naming and ordering of objects or processes renegotiated in an age where nomenclatures, taxonomies or bibliographies become outdated ever more rapidly? What kind of credit accompanies the development of methods or compilation of data in general? Why do certain manuals and handbooks become commercially successful or canonical while others become outdated, even antiquated? How does their circulation relate to the commodification of required materials, or to more informal forms of exchange? By following editions of protocols or manuals the historian can track the transmission of knowledge across time, space, media or language, and note

38 Projit B. Mukharji, Doctoring Traditions: Ayurveda, Small Technologies, and Braided Sciences, Chicago: The University of Chicago Press, 2016.

39 David Edgerton, The Shock of the Old: Technology and Global History since 1900, London: Profile Books, 2006.

40 Matthew D. Eddy, 'Tools for reordering: commonplacing and the space of words in Linnaeus's Philosophia Botanica', Intellectual History Review (2010) 20, pp. 227-52.

41 Mathias Grote, 'Vintage physiology: Otto Warburgs “Labor-Kochbücher” und Apparaturen', NTM Zeitschrift für Geschichte der Naturwissenschaften, Technik und Medizin (2013) 21, pp. 171-85. 
necessary and accompanying amendments and adaptations. ${ }^{42}$ We believe that juxtaposing the new and the old can shed light on how knowledge is made and maintained - as well as how it is acquired in the first place. ${ }^{43}$ The expectation with electronic media that knowledge be utterly up to date might be scrutinized in light of earlier efforts to harness new media to solve problems of knowledge. Our case studies also suggest that learning by the book can constrain or streamline cognitive processes by omitting or excluding other ways of doing. Herein lies the tension at the heart of manuals, handbooks and related media they concurrently enable flow of knowledge and they fix it.

Finally, the recent shift to Web-based media has turned some printed manuals and handbooks into archaic remnants of the past, on account of format as well as content. Our collection abuts recent historical studies of digital reference media like databases and opens up a frame for analysing other formats, such as video-clip instructions. ${ }^{44}$ It is equally remarkable that, parallel to this rise of digital technology, instructional and ready-reference literature has remained as prominent both online and in print as we have collectively found it to be in the past. Publishers continue to offer long series of handbooks, guidebooks (Ratgeber) and do-it-yourself or self-help tutorials on a variety of topics from craft beer to counselling. ${ }^{45}$

Learning know-how in person, whether formally in a structured apprenticeship or informally within a knowledge community, has always prefigured the genre of text that is at stake in this volume. In the twenty-first century, this relationship has shifted once more, as seen in the displacement of the formerly ubiquitous owner's manuals by instructional videos on YouTube. These days the master teaches us how to do something by talking to a camera, usually while demonstrating, instead of writing a book. Is this a return to past practice, or just the reinvention of the manual in a new guise? What are we to make of the fact that search engines, databases and Wiki-projects put seemingly all information 'at hand' while making certain, or at least certified, knowledge possibly harder to grasp than when we visit the library reference room? As we continue to assess how the Internet both has and has not altered learning, this volumes' collective history of handbooks and manuals across time and space may well prove to be a useful guide.

Acknowledgements. Support from the German Historical Institute Washington, Princeton University and the Max Planck Institute for the History of Science made possible the meetings that resulted in this volume. Kerstin von der Krone, Mark Stoneman, Jennifer Loessy, Regina Held, Anna Radetckaia, Sally Cochrane and Laura Selle deserve special thanks, as do some key interlocutors: Sven Dupré, Tony Grafton, Evan Hepler-Smith, Florence Hsia, Pamela Smith and Heinrich von Staden. We thank Simon Werrett, the other contributors to this collection and two anonymous referees for their suggestions on drafts.

42 James A. Secord, 'Knowledge in transit', Isis (2004) 95, pp. 654-72.

43 Andrew L. Russell and Lee Vinsel, 'After innovation, turn to maintenance', Technology and Culture (2018) 59, pp. 1-25.

44 Sabina Leonelli, 'Making sense of data-driven research in the biological and biomedical sciences', Studies in the History and the Philosophy of the Biological and Biomedical Sciences (2012) 43, pp. 1-3; Bruno J. Strasser, 'Collecting nature: practices, styles and narratives', Osiris (2012) 27, pp. 303-40.

45 On guidebooks/Ratgeber, especially regarding contemporary conceptions of the self, see Sabine Maasen, 'Es ist Ihre Entscheidung! Die Hypostasierung der Wahl in Ratgeberbüchern', in Friedrich Balke, Gregor Schwering and Urs Stäheli (eds.), Paradoxien der Entscheidung, Bielefeld: De Gruyter, 2003, pp. 211-42.

Cite this article: Creager ANH, Grote M, Leong E (2020). Learning by the book: manuals and handbooks in the history of science. BJHS Themes 5, 1-13. https://doi.org/10.1017/bjt.2020.1 